\section{AEC \\ RESEARCH and}

DEVELIOPMENT REPORT

\title{
ELECTROCHEMISTRY OF PLUTONIUM(III) IN MOLTEN ALKALI CHLORIDES
}

\author{
D. A. NISSEN \\ D. A. NISSEN
}

NOVEMBER, 1965

BNWL-158

$23=$

NOVEMBER, 1965
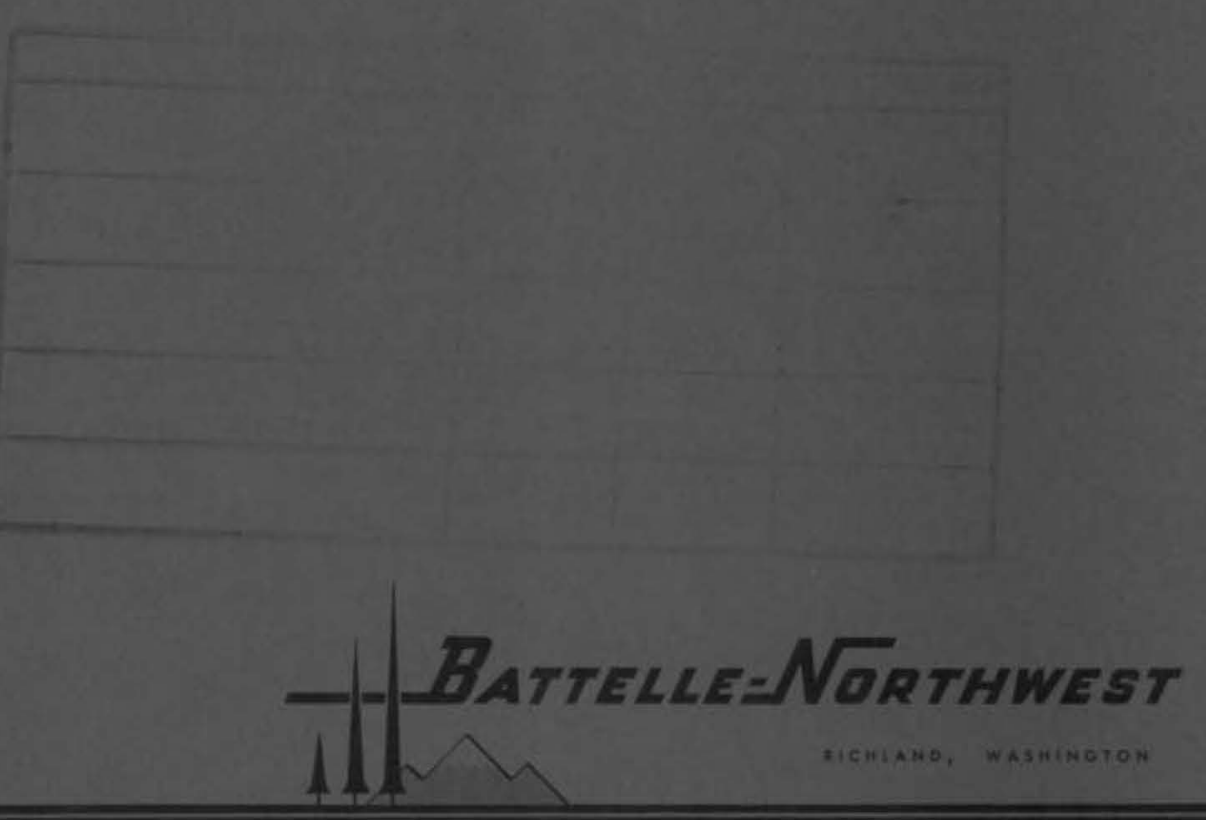

PACIFIC NORTHWEST LABORATORY operated bY BATTELLE MEMORIAL INSTITUTE 
This report was prepared as an account of Government sponsored work. Neither the United States, nor the Commission, nor any person acting on behalf of the Commission:

A. Makes any warranty or representation, expressed or implied, with respect to the accuracy, sompleteness, or usefulness of the information contained in this report, or that the use of any information, apparatus, method, or process disclosed in this report may not infringe privately owned rights; or

B. Assumes any liabilities with respect to the use of, or for damages resulting from the use of any information, apparatus, method, or process disclosed in this report.

As used in the above, "person acting on behalf of the Commission" includes any employee or contractor of the Commission, or employee of such contractor, to the extent that such employee or con. tractor of the Commission, or employee of such coniractor prepares, disseminates, or provides access to, any information pursuant to his employment or contract with the Commission, or his employment with such coniractor.

\section{PACIFIC NORTHWEST LABORATORY \\ RICHLAND, WASHINGTON \\ operated by \\ BATTELLE MEMORIAL INSTITUTE}

for the

UNITED STATES ATOMIC ENERGY COMMISSION UNDER CONTRACT AT(45-1)-1830 


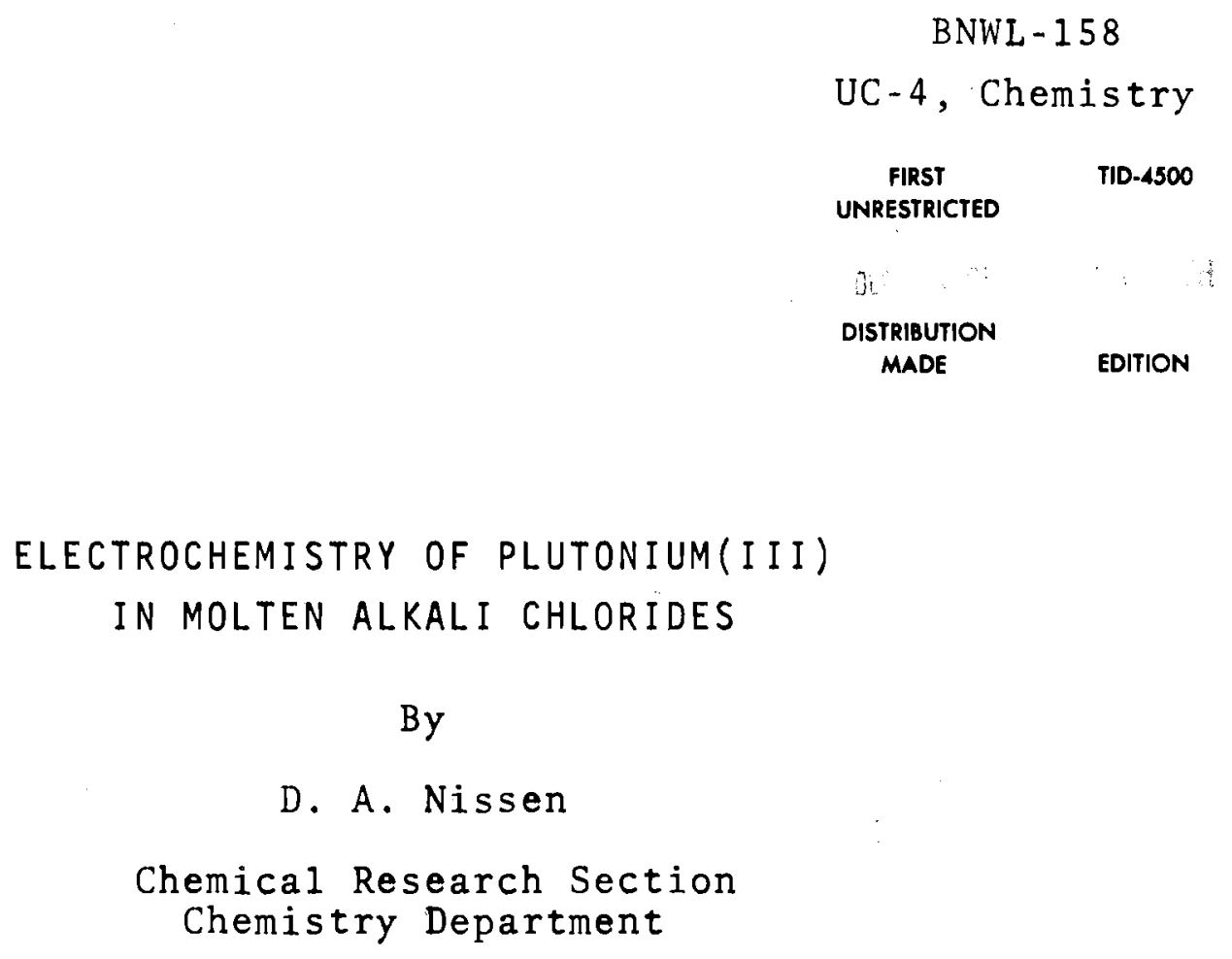

November, 1965

PACIFIC NORTHWEST LABORATORY

RICHLAND, WASHINGTON 


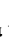

1

$\checkmark$

1. 


\section{ELECTROCHEMISTRY OF PLUTONIUM(III) IN MOLTEN ALKALI CHLORIDES}

\section{INTRODUCTI ON}

Chronopotentiometric and cyclic voltametric techniques have been used to study the electrochemical reduction of Pu(III) to the metal in molten chloride solutions, in particular, the eutectic LiCl/KCl system. A postulated mechanism for the cathodic reduction of Pu(III) in this me1t system as well as information on its diffusion properties are presented in this report.

Current interest in the use of molten salts as media for processing nuclear fuels, especially for the electrowinning $(1)$ and electrorefining (2) of plutonium metal, has demonstrated the need for a fundamental study of the electrochemistry of plutonium in molten salts.

With the exception of the work of Benz $(3,4)$ on thermodynamic values for the reaction

$$
\mathrm{Pu}+3 / 2 \mathrm{Cl}_{2} \leftrightarrows \mathrm{PuCl}_{3}
$$

in molten LiCl and $\mathrm{NaCl}$, very little is known about the electrochemistry of the Pu/Pu(III) couple in molten media. of particular interest is the possibility that Pu(III) may undergo an initial reduction to a lower oxidation state before being reduced to the metal. The existence of a stable plutonium valence state lower than three would be of interest from a theoretical as well. as a practical st andpoint.

\section{SUMMARY}

The change-transfer reaction apparently takes place in one step, involving a three electron change. There is no evidence that the cathodic reduction of $\mathrm{Pu}($ III) to the metal passes through a stable lower oxidation state in the LiCl/KCl melt system.

The results of chronopotentiometric experiments show that Pu(III) exhibits dissimilar behavior as the temperature of the melt is changed. At $400{ }^{\circ} \mathrm{C}$ a characteristic function, the $i_{0}{ }^{1 / 2}$ product, is invariant with current density. At higher temperatures this function changes as the current density changes. It would appear on this basis that at $400{ }^{\circ} \mathrm{C}$ plutonium, possibly in the form of a complex molecule, undergoes direct reduction to the metal. At temperatures in excess of $400{ }^{\circ} \mathrm{C}$, an equilibrium apparently exists between two complex species of plutonium; and the rate of transformation from one form to another is the rate controlling step.

Except for the fact that Pu(III) undergoes a single three-electron reduction to the metal, the mechanism is uncertain. It is anticipated that electrochemical relaxation techniques coupled with proposed spectrophotometric studies will be helpful in defining the reduction mechanism more exact $1 y$.

\section{EXPERIMENTAL}

\section{Cell and Instruments}

The melt was contained in a graphite crucible which in turn was enclosed in a quartz cell. The top 
of the cell was flanged and ground flat to provide a seal with the 1 id which was fabricated from Pyrex and had standard taper joints fastened to it. Such things as electrodes, etc., which were to be put into the cell were equipped with standard taper joints; in this way a sealed system was provided, and a controlled atmosphere could be kept over the melt.

Electrodes for the chronopotentiometric experiments were cut from $7 \mathrm{mil}$ tungsten sheet, spot welded to a $10 \mathrm{mil}$ tungsten wire, and polished to a mirror finish. Electrodes for cyclic voltametric studies were made by sealing a 24 gage tungsten wire into vycor tubing. These wires were then polished to try to produce as uniform a surface as possible.

A $\mathrm{Ag} / \mathrm{AgCl}$ half-cell (0.1 molal $\mathrm{AgCl}$ in $\mathrm{LiCl} / \mathrm{KCl}$ ) served as the reference electrode for both the chronopotentiometric and cyclic voltametric studies. It was separated from the main body of the melt by a Pyrex membrane. In some cases, for the sake of convenience, a spectrographic grade graphite rod which dipped into the melt acted as a quasi-reference electrode. Although the graphite assumes a mixed potential of unknown magnitude, its value was constant (within $\pm 1 \mathrm{mV}$ ) over extended periods of time.

The melt temperature for these experiments was maintained within \pm 2 ${ }^{\circ} \mathrm{C}$ by the use of a vertical, nichrome wire-wound resistance furnace controlled by a wheelco indicating millivolt meter.

A chronopotentiometric circuit, previously described by Delahay, (5) was coupled with an oscillographic recorder which was used to record the potential of the tungsten indicating electrode as a function of time. Details of the instrument can be found in the paper by stromatt. (6) The cyclic voltameter was was based on one described by Alden. (7)

\section{Me 1 t Preparation}

To obtain reproducible and meaningful results, it was necessary to exercise the most extreme care in the preparation of the melt. The sequence of operations included prolonged treatment of the $\mathrm{LiCl/KCl}$ solvent, both unfused and molten, with HCl followed by a preelectrolysis of the melt at -1.9 versus the $\mathrm{Ag} / \mathrm{AgCl}$ reference electrode. A blank melt of high purity could be produced by taking appropriate precautions (having a chronopotentiometric transition time of less than $0.01 \mathrm{sec}$ at $-1.9 \mathrm{~V}$ ). After any additions to the melt were made it was treated with HCl for about $6 \mathrm{hr}$.

Helium, which had been purified by passing over zirconium turnings maintained at $750{ }^{\circ} \mathrm{C}$ and then through $\mathrm{Mg}\left(\mathrm{ClO}_{4}\right)_{2}$, was used to provide an inert atmosphere over the melt.

To insure that the graphite crucible which was used to contain the melt did not act as a source of contamination, it was boiled in concentrated hydrochloric acid, then in distilled water, and thoroughly dried before being used.

A11 preparative and experimental work was done in a glove box through which a flow of predried air was passed. 


\section{RESULTS}

Among the several techniques available for studying electrode reaction mechanisms and diffusion properties, two were chosen for this study: cyc1 ic voltametry and chronopotentiometry. The first of these techniques, cyclic voltametry, is simply a variation of a more classical electrode polarization technique, polarography. In cyclic voltametry, the potential of the polarized electrode is made to vary periodically within set limits and the resulting current is recorded as a function of voltage.

Figure 1 shows a typical voltamagram for the reduction of Pu(III) to the metal, followed by oxidation of

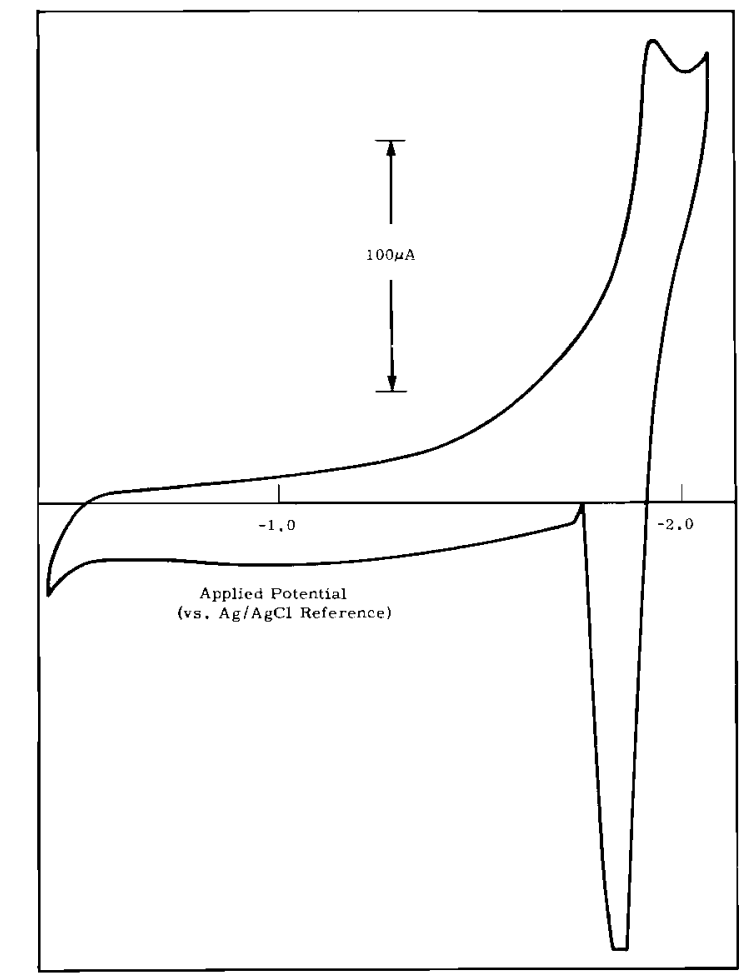

EIGURE 1. VOLTAMAGRAM OE PU(III) AT A TUNGSTEN MICROELECTRODE IN LICL/KCZ AT $400{ }^{\circ} \mathrm{C}$. CONCENTRATION OF PU(III) $=1.65 \times 10^{-5}$ moles $/ \mathrm{cm}^{3}$ the metal1ic deposit, at $400{ }^{\circ} \mathrm{C}$ in the eutectic LiC1/KC1 system. Reduction of $\mathrm{Pu}$ (III) to the metal takes place at about $-0.84 \mathrm{~V}$ and is followed by reduction of the solvent at about -2.1 versus the $\mathrm{Ag} / \mathrm{AgCl}$ reference electrode. The subsequent oxidation step occurs as a single peak which has a form characteristic of the oxidation of a solid product. There appears to be no evidence that the reduction step passes through a stable subvalent state in this melt system. From the proximity of the reduction and oxidation potential, one can conclude that the reduction process, at $400^{\circ} \mathrm{C}$, is reversible.

Chronopotentiometry is simply an electrolysis technique in which a current pulse of predetermined magnitude and duration is applied to an electrochemical cell under conditions of 1 inear diffusion while recording the potential of the test electrode as a function of time. An important experimental quantity in chronopotentiometry is the transition time, $\tau$. This is the time interval after the onset of electrolysis when the surface concentration of the electroactive material diffusing the electrode reaches zero and a jump of the electrode potential occurs.

Figure 2 shows a typical chronopotentiogram for the same system and temperature as for Figure 1. In this case, as in the preceding one, there is no evidence for a stable subvalent state of plutonium; no intermediate reduction steps are apparent before the final one which is the reduction to the metal. 


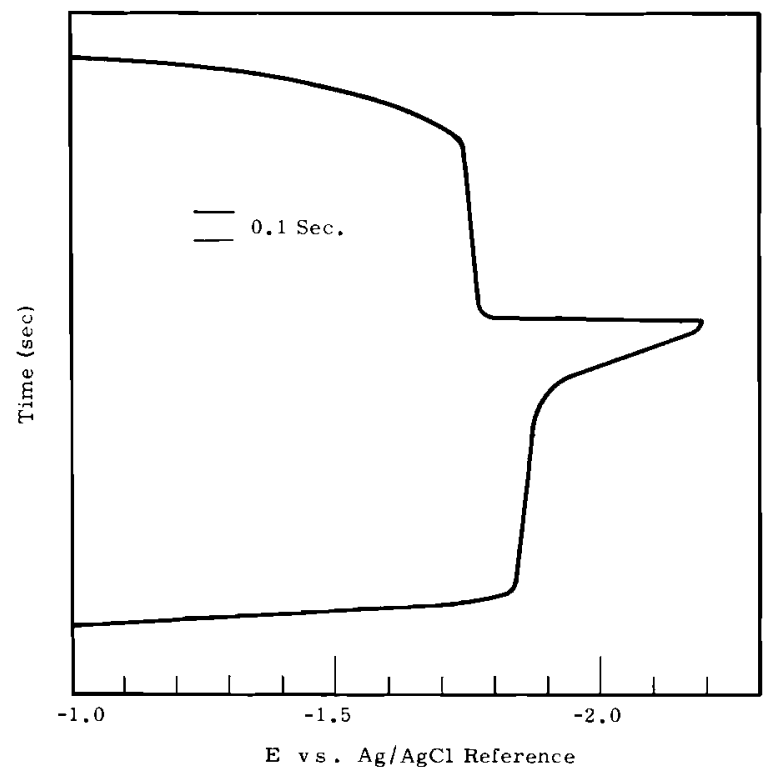

FIGURE 2. CURRENT-REVERSAL CHRONOPOTENTIOGRAM OF PU(III) AT A TUNGSTEN ELECTRODE (ELECTRODE AREA $1.16 \mathrm{~cm}^{2}$ ) AT $400{ }^{\circ} \mathrm{C}$ IN LiCl/KCl. CONCENTRATION OF PU(III) $=1.65 \times 10^{-5} \operatorname{moles} / \mathrm{cm}^{3}$

Figure 3 presents the data from chronopotentiometric experiments as a plot of the product of the current density, $i_{0}$, and the square root of the transition time, $\tau^{1 / 2}$, versus the current density for various values of the temperature and concentration of $\mathrm{PuCl}_{3}$ in the eutectic LiCl/KCl system.

The $i_{0} \tau^{1 / 2}$ product shows two different characteristics: at $400{ }^{\circ} \mathrm{C}$ it is invariant with current density (for $\left.i_{0}>2 \times 10^{-2} \mathrm{~A} / \mathrm{cm}^{2}\right)$; at 500 and 600 ${ }^{\circ} \mathrm{C}$ the $i_{0} \tau^{1 / 2}-i_{0}$ relationship has a finite slope.

\section{DISCUSSION}

The relationship between the transition time and the current density for a reaction sequence of the type

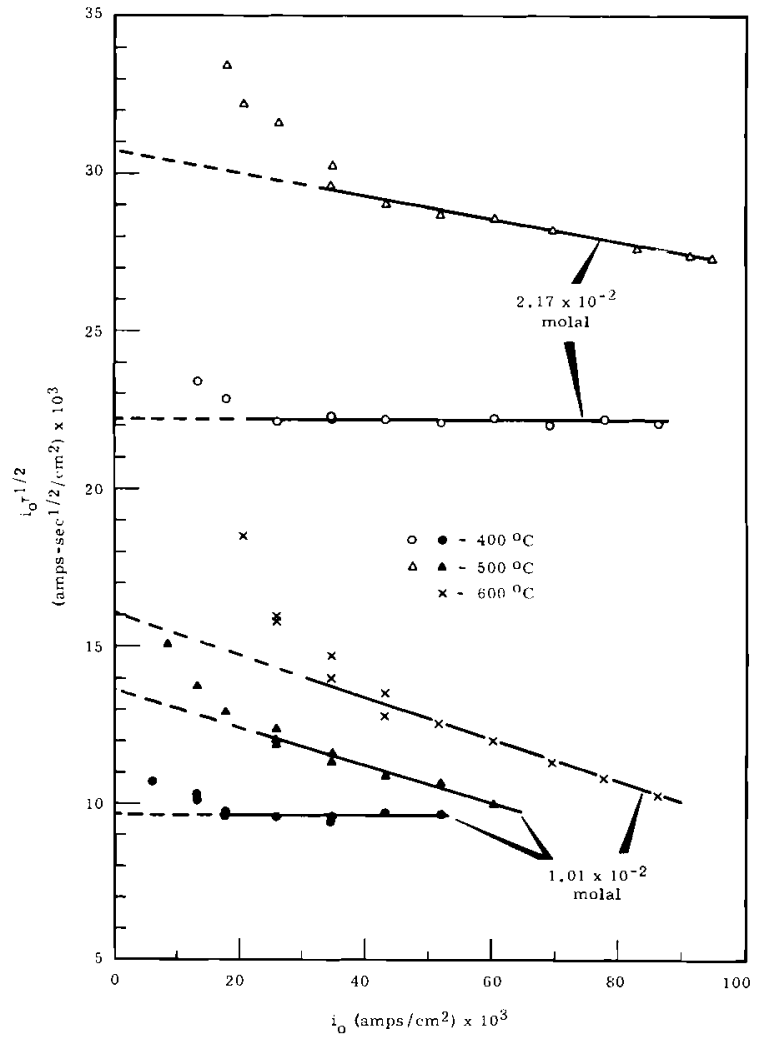

FIGURE 3. THE i $0 \tau^{1 / 2}$ PRODUCT ASA FUNCTION OF i 0 FOR PU(III) AT A TUNGSTEN ELECTRODE (ELECTRODE AREA $1.16 \mathrm{~cm}^{2}$ ) IN LiCZ/KCZ AT VARTOUS TEMPERATURES AND CONCENTRATIONS OF PU(III)

$$
\mathrm{O}_{1} \underset{\overrightarrow{\mathrm{k}}_{\mathrm{f}}}{\stackrel{\mathrm{k}}{\rightarrow}} \mathrm{O}_{2} \underset{\rightarrow}{\mathrm{ne}} \mathrm{R}
$$

is given by the equation (8)

$$
\begin{aligned}
i_{o}{ }^{1 / 2}= & \frac{n F C(\pi D){ }^{1 / 2}}{2}-\frac{\pi i_{o}}{2 K\left(k_{f}+k_{b}\right)^{1 / 2}} \\
& \cdot \operatorname{erf}\left[\left(k_{f}+k_{b}\right)^{1 / 2}{ }_{\tau}^{1 / 2}\right]
\end{aligned}
$$

where $\quad K=$ the equilibrium constant

$k_{f}$ and $k_{b}=$ the formal rate constants for the chemical reaction which, in Equation (1), precedes the chargetransfer reaction 


$$
\begin{aligned}
\mathrm{C}= & \text { the concentration in } \\
& \text { moles/cm } \\
\mathrm{D}= & \text { the diffusion coeffi }- \\
& \text { cient in } \mathrm{cm}^{2} / \mathrm{sec} \\
\mathrm{i}_{\mathrm{O}}= & \text { the current density in } \\
& \mathrm{A} / \mathrm{cm}^{2} \\
\tau= & \text { the transition time in } \\
& \text { seconds } \\
\mathrm{n}= & \text { the number of electrons } \\
& \text { involved in the charge- } \\
& \text { transfer reaction } \\
\mathrm{F}= & \text { the value of the Faraday } \\
& (96,500 \text { coulombs/equiv.). }
\end{aligned}
$$

In those cases where the argument of the error function is greater than

2, Equation (2) reduces to

$$
i_{o} \tau^{1 / 2}=\frac{n F C(\pi D))^{1 / 2}}{2}-\frac{\pi i_{o}}{2 K\left(k_{f}+k_{b}\right)^{1 / 2}}
$$

This equation predicts that the $i_{0} \tau^{1 / 2}-i_{0}$ relationship should be 1 inear with a slope equal to

$$
-\frac{\pi / 2}{2 k\left(k_{f}+k_{b}\right)^{1 / 2}}
$$

and an intercept equal to

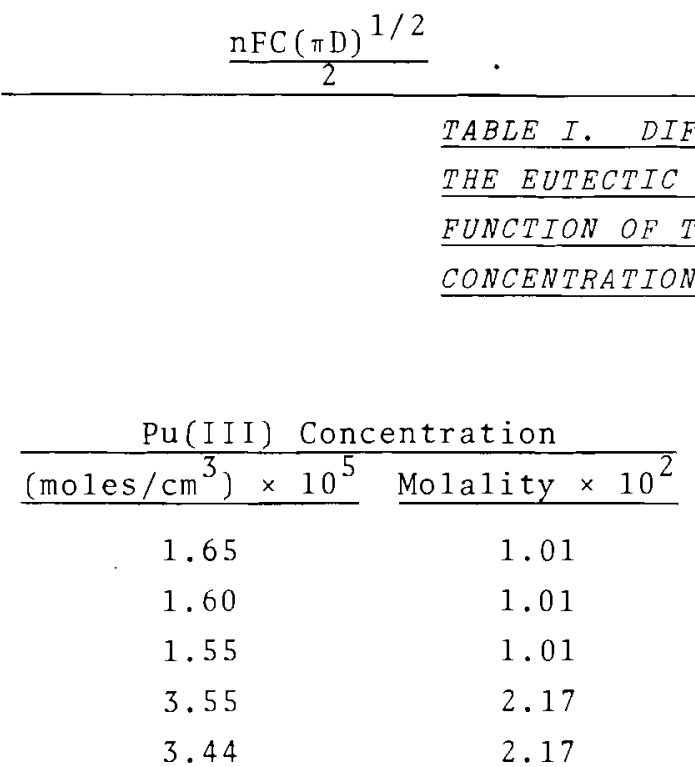

CONCENTRATION
Pu(III) Concentration

$\begin{array}{ll}1.65 & 1.01 \\ 1.60 & 1.01 \\ 1.55 & 1.01 \\ 3.55 & 2.17 \\ 3.44 & 2.17\end{array}$

If the quantity $K\left(k_{f}+k_{b}\right)^{1 / 2}$ is sufficiently large $\left(<500 \mathrm{sec}^{-1 / 2}\right)$, the slope becomes essentially equal to zero and Equation (3) reduces to

$$
i_{0} \tau^{1 / 2}=\frac{\operatorname{nFC}(\pi \mathrm{D})^{1 / 2}}{2}
$$

which gives the relationship between the transition time and the current density for a simple diffusioncontrolled process and predicts that the $i_{0} \tau^{1 / 2}$ product should be invariant with $i_{0}$.

Using the applicable equations, as discussed earlier, and the information given in Figure 3 , values of the diffusion coefficient for Pu(III) have been calculated for various temperatures and plutonium concentrations. These values are given in Table I.

The values of the diffusion coefficient given in Table I for $\mathrm{Pu}(\mathrm{III})$ in molten $\mathrm{LiCl} / \mathrm{KCl}$ are in reasonable a agreement with those determined for $B i(I I I)$ in the same solvent system by Laitinen and Ferguson, $0.68 \times 10^{-5}$ at $400{ }^{\circ} \mathrm{C},(9)$ and by Thalmayer et a 1 , 0 $0.63 \times 10^{-5}$ at $400{ }^{\circ} \mathrm{C}$ and $1.0 \times 10^{-5}$ at $450{ }^{\circ} \mathrm{C}$.

TABLE I. DIFFUSION COEFFICIENTS FOR

THE EUTECTIC LICL/KCL SYSTEM AS A

FUNCTION OF TEMPERATURE AND PLUTONIUM

Temperature ${ }^{\circ} \mathrm{C}$ 400 500 600 400 500<smiles>[TeH][TeH]</smiles>
Diffusion Coefficient

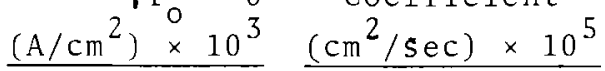
$9.6 \quad 0.51$ $13.7 \quad 1.11$ $16.0 \quad 1.62$ $22.2 \quad 0.59$ $30.8 \quad 1.21$ 
The temperature dependence of the diffusion coefficient is a measure of the activation energy for the diffusion of $\mathrm{Pu}(\mathrm{III})$. A plot of the $\log$ arithm of the diffusion coefficients shown in $\mathrm{Table} I$ versus the reciprocal of the absolute temperature is linear and yields an activation energy of $6.7 \mathrm{kcal} / \mathrm{mole}$.

Figure 3 shows that the values of $i_{0} \tau^{1 / 2}$ depart markedly from linearity at low current density for all values of the temperature. There are two possible explanations which might account for this.

If convection currents had been present in the melt, they would have caused an enchancement of the transition time by increasing the amount of electroactive material at the electrode over that which would have been available on the basis of diffusion alone. In no case, however, was the transition time longer than about $3 \mathrm{sec}$. Measurement of the transition time for the reduction of $C d(I I)$ in a similar experimental setup showed that there was no interference from convection for transition times up to $5 \mathrm{sec}$ (11)

This same departure from linearity was noted by Gierst and Juliard(12) and was attributed to an increase in the cathode area due to the formation of dendritic growths. If this was the case in these experiments, this phenomena should disappear at temperatures in excess of $640{ }^{\circ} \mathrm{C}$, the melting point of plutonium metal; however, experimental difficulties prevented an examination of this system at temperatures in excess of $600{ }^{\circ} \mathrm{C}$.

\section{ACKNOWLEDGEMENT}

The author wishes to express his appreciation to Dr. R. W. Stromatt for his invaluable assistance. 


\section{REFERENCES}

1. M. H. Curtis and H. H. Hopkins, Jr. "Continuous Electrowinning of Dlutonium from Chloride Melts," Electrochemical Technology, vol. 2, p. 239.1964 .

2. L. J. MuZZins and J. A. Leary. Report LA-DC-6401. Los Alamos Scientific Laboratory, 1964.

3. R. Benz. "Some Thermodynamic Properties of the System $\mathrm{PuCl}_{3}$ $\mathrm{KCl}$ from Electromotive Force Data," J. Phys. Chem., vol. 65, p. 81. 1961.

4. R. Benz. "Some Thermodynamic Properties of the system $\mathrm{PuCl}_{3}$ NaCl from Electromotive Force ${ }^{3}$ Data," J. Phys. Chem., vol. 65, p. 1056.1961 .

5. P. Delahay. New Instrumental Methods in Electrochemistry, Interscience Publishers Inc., New York, 1954.

6. R. W. Stromatt. "Studies on the Electrodreduction of Urany Z(VI) in Molten Equimolar KCZ-NaCZ by Chronopotentiometric and Electrode Impedance Measurements," J. Electrochem. Soc., vol. 110 , p. 1277. 1963.

7. J. R. Alden, J. Q. Chambers, and $R$. H. Adams. "Operational
Amplifier Circuits for Controlled Potential Cyclic Voltammeters. II, J. Electroanalytical Chem., vol. 5, p. 152. 1963.

8. P. Delahay and T. Berzins. "Theory of Electrolysis at Constant Current with Partial or Total Control by DiffusionApplication to the Study of Complex Ions," J.Am. Chem. Soc., vol. 75, p. 2486.1953 .

9. H. A. Laitinen and W. S. Ferguson. "Chronopotentiometric Analysis in Fused Lithium Chloride-Potassium Chloride," Analytical Chemistry, vol. $29, p .4$. 1957.

10. C. E. Thalmeyer, S. Bruckenstein, and D. M. Gruen. "Chronopotentiometric Determination of Interdiffusion Coefficients and Heat of Interdiffusion in Molten Salts," J. of Inorganic and Nuclear Chem., vol. 26, p. 347. 1964.

11. R. L. Braun and R. W. Stromat. Unpublished Data.

12. L. Gierst and A. JuZiard. "Etude oscillographique des Régimes Transitoires de Diffusion," Proc. Intern. Comm. Electrochem., Thermodynam., and Kinet., 2nd Meeting Tamburini, Milan, p. 117. 1950 . 
u

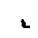
$\checkmark$ 
ONSITE DISTRIBUTION

Copy Number

\begin{tabular}{cl} 
Pacific & Northwest Laboratory \\
\hline 1 & L. L. Burger \\
2 & G. M. Dalen \\
3 & K. M. Harmon \\
4 & R. H. Moore \\
5 & R. L. Moore \\
$6-15$ & D. A. Nissen \\
16 & T. S. Soine \\
17 & R. W. Stromatt \\
18 & W. H. Swift \\
19 & E. E. Voiland \\
20 & O. J. Wick \\
$21-25$ & Technical Information \\
26 & File \\
& Poo Area Technical \\
27 & 700 Area Technical \\
& Publications
\end{tabular}

General Electric Company

28 H. H. Hopkins, Jr.

29 R. J. Sloat

30 R. E. Tomlinson

31 GETA Files

Richland Operations Office

32 R. K. Sharp

33 Technical Information

Library 
